\title{
Cow-specific treatment of clinical mastitis: An economic approach
}

\author{
W. Steeneveld, ${ }^{* 1,2}$ T. van Werven, ${ }^{*}$ H. W. Barkema, $†$ and H. Hogeveen ${ }^{*} \ddagger$ \\ *Department of Farm Animal Health, Faculty of Veterinary Medicine, Utrecht University, $3584 \mathrm{CL}$, Utrecht, the Netherlands \\ †Department of Production Animal Health, Faculty of Veterinary Medicine, University of Calgary, Calgary, T2N 4N1 Canada \\ ‡Chair group Business Economics, Wageningen University, $6706 \mathrm{KN}$, Wageningen, the Netherlands
}

\begin{abstract}
Under Dutch circumstances, most clinical mastitis $(\mathrm{CM})$ cases of cows on dairy farms are treated with a standard intramammary antimicrobial treatment. Several antimicrobial treatments are available for CM, differing in antimicrobial compound, route of application, duration, and cost. Because cow factors (e.g., parity, stage of lactation, and somatic cell count history) and the causal pathogen influence the probability of cure, cow-specific treatment of $\mathrm{CM}$ is often recommended. The objective of this study was to determine if cowspecific treatment of $\mathrm{CM}$ is economically beneficial. Using a stochastic Monte Carlo simulation model, 20,000 CM cases were simulated. These CM cases were caused by Streptococcus uberis and Streptococcus dysgalactiae (40\%), Staphylococcus aureus (30\%), or Escherichia coli (30\%). For each simulated CM case, the consequences of using different antimicrobial treatment regimens (standard 3-d intramammary, extended 5-d intramammary, combination 3-d intramammary + systemic, combination 3-d intramammary + systemic +1 -d nonsteroidal antiinflammatory drugs, and combination extended 5-d intramammary + systemic) were simulated simultaneously. Finally, total costs of the 5 antimicrobial treatment regimens were compared. Some inputs for the model were based on literature information and assumptions made by the authors were used if no information was available. Bacteriological cure for each individual cow depended on the antimicrobial treatment regimen, the causal pathogen, and the cow factors parity, stage of lactation, somatic cell count history, CM history, and whether the cow was systemically ill. Total costs for each case depended on treatment costs for the initial CM case (including costs for antibiotics, milk withdrawal, and labor), treatment costs for follow-up CM cases, costs for milk production losses, and costs for culling. Average total costs for CM
\end{abstract}

\footnotetext{
Received April 23, 2010.

Accepted September 27, 2010.

${ }^{1}$ Corresponding author: wilma.steeneveld@wur.nl

${ }^{2}$ Current address: Chair group Business Economics, Wageningen University, Hollandseweg 1, 6706 KN Wageningen, the Netherlands.
}

using the 5 treatments were (US) $\$ 224, \$ 247, \$ 253$, $\$ 260$, and $\$ 275$, respectively. Average probabilities of bacteriological cure for the 5 treatments were 0.53 , $0.65,0.65,0.68$, and 0.75 , respectively. For all different simulated CM cases, the standard 3-d intramammary antimicrobial treatment had the lowest total costs. The benefits of lower costs for milk production losses and culling for cases treated with the intensive treatments did not outweigh the higher treatment costs. The stochastic model was developed using information from the literature and assumptions made by the authors. Using these information sources resulted in a difference in effectiveness of different antimicrobial treatments for CM. Based on our assumptions, cow-specific treatment of CM was not economically beneficial.

Key words: clinical mastitis, antimicrobial treatment, economics, dairy cow

\section{INTRODUCTION}

Mastitis is one of the most frequently occurring and costly diseases in dairy cows (e.g., Halasa et al., 2007). Most mild clinical mastitis $(\mathbf{C M})$ cases are treated with a 3-d intramammary treatment. However, several antimicrobial treatment regimens are available for CM, differing in antimicrobial compound, route of application, duration, probability of cure, and costs (e.g., Barkema et al., 2006). Other treatment options are to use nonsteroidal antiinflammatory drugs (NSAID) in combination with an antimicrobial treatment (McDougall et al., 2009) or immediate culling (Bar et al., 2008a). The probability of cure depends highly on the causal pathogen of CM (e.g., McDougall et al., 2007; Bradley and Green, 2009). The probability of cure is determined by the treatment regimen and the causal pathogen, but several cow factors also influence the success of treatment. For instance, Sol et al. (2000) and Barkema et al. (2006) mentioned that the probability of cure of Staphylococcus aureus CM depends, for instance, on the cow factors SCC and parity.

On an increasing number of dairy farms, information on cow factors that may influence the probability of cure is available automatically via management programs. A farmer has to consider all information sources 
Table 1. Probabilities used to determine the parity of the cow, whether the cow with clinical mastitis was systemically ill, and whether the clinical mastitis case is a repeated case, given the causal pathogen of clinical mastitis

\begin{tabular}{lccccccccc}
\hline & \multicolumn{2}{c}{ Parity } & & \multicolumn{2}{c}{ Systemically ill } & & \multicolumn{2}{c}{ Repeated case } \\
\cline { 2 - 3 } \cline { 8 - 9 } \cline { 8 - 9 } Causal pathogen & 1 & $\geq 2$ & & Yes & No & & Yes & No \\
\hline Streptococci & 0.19 & 0.81 & & 0.10 & 0.90 & & 0.10 & 0.90 \\
Staphylococcus aureus & 0.18 & 0.82 & & 0.06 & 0.94 & & 0.12 & 0.88 \\
Escherichia coli & 0.15 & 0.85 & & 0.31 & 0.69 & & 0.05 & 0.95 \\
\hline
\end{tabular}

when making treatment decisions for a cow with CM. Because people can only use a maximum number of information sources to make the optimal decision (Miller, 1956), making the optimal decision for treatment of $\mathrm{CM}$ based on all available information sources is very difficult. Combining information on several treatment options and all cure-influencing cow factors in an automated decision support model would be useful to support farmers in their decisions on the optimal CM treatment. Bar et al. (2008b) presented a dynamic programming model to support farmers in making CM treatment decisions. In their model, however, it was not possible to choose between different antimicrobial treatment regimens for individual cows.

The importance of optimizing the choice of CM treatment is stressed frequently (Barkema et al., 2006; Bar et al., 2008b; Steeneveld et al., 2009). However, before developing a computerized decision support model for treatment of CM, we must determine whether optimizing the choice of treatment is worthwhile. The optimal $\mathrm{CM}$ treatment is often measured in terms of clinical or bacteriological cure. Barkema et al. (2006), however, mentioned that dairy farming is an economic enterprise and therefore the real measure of cure should be the cost-benefit of treatment. So far, no study has determined whether making cow-specific CM treatment decisions is economically beneficial. The overall objective of this study was to determine if cow-specific treatment of CM is economically beneficial.

\section{MATERIALS AND METHODS}

\section{Model Development}

A stochastic Monte Carlo simulation model, at cow level, was built to calculate the costs of $\mathrm{CM}$ cases treated with different treatment regimens using Microsoft Excel with @Risk add-in software (2002; Palisade Corp., Newfield, NY). Model outcomes were generated in 3 steps. First, each iteration (20,000 in total) during the simulation process yielded a specific cow with CM. In the second step, treating the simulated CM case was simulated using 6 defined treatment regimens (5 different antimicrobial treatment regimens and im- mediate culling). The third step involved calculation of the associated total costs for CM under each of the 6 treatment regimens. All discrete events and variability with regard to the modeled CM cases under the 6 different treatment regimens were triggered stochastically using random numbers drawn from relevant distributions. These distributions were based on knowledge of the model domain, information from the literature and, if no other information was available, on assumptions made by the authors.

\section{Simulation of a Cow with CM}

The causal pathogen of the CM case was determined using a discrete probability distribution. In our model, the CM case could be caused by streptococci (Streptococcus uberis and Streptococcus dysgalactiae; probability $=0.40)$, Staphylococcus aureus (probability $=0.30$ ) or Escherichia coli (probability $=0.30$ ). This pathogen distribution was based on results of Barkema et al. (1998) and Olde Riekerink et al. (2007). The length of the calving interval of the cow with CM was determined with a pert probability distribution with a minimum of $336 \mathrm{~d}$, a most likely value of $410 \mathrm{~d}$, and a maximum of 556 d (CRV, 2009). Subsequently, using a dry period of $60 \mathrm{~d}$, the length of lactation was $60 \mathrm{~d}$ shorter than the calving interval. The parity of the cow (heifer or older cow), whether the cow was systemically ill, and whether the CM case was a repeated case were determined with discrete probability distributions, where probabilities were dependent on the causal pathogen. The month in milk of $\mathrm{CM}(1,2,3, \ldots, \geq 8)$ was determined with a discrete probability distribution, where probabilities were dependent on the causal pathogen and parity. When the month in milk was determined, a uniform probability distribution was used to determine the exact day of CM occurrence in that specific month in milk. The 305-d milk production of the cow with CM was modeled assuming a normal distribution. A mean 305-d milk production for heifers and older cows of 7,434 and 8,666 kg, respectively, was used (CRV, 2009). The daily milk production at the moment of CM and the remaining milk production after the CM case 
Table 2. Probabilities used to determine the month in milk, given the parity of the cow and the causal pathogen of clinical mastitis

\begin{tabular}{|c|c|c|c|c|c|c|c|c|c|c|c|c|c|c|c|c|}
\hline Causal pathogen & \multicolumn{8}{|c|}{ Parity 1 (month in milk) } & \multicolumn{8}{|c|}{ Parity $\geq 2$ (month in milk) } \\
\hline Streptococci & 0.60 & 0.13 & 0.08 & 0.02 & 0.05 & 0.05 & 0.02 & 0.05 & 0.25 & 0.16 & 0.16 & 0.10 & 0.08 & 0.06 & 0.07 & 0.12 \\
\hline Escherichia coli & 0.36 & 0.16 & 0.11 & 0.09 & 0.03 & 0.06 & 0.07 & 0.12 & 0.26 & 0.18 & 0.14 & 0.12 & 0.10 & 0.08 & 0.04 & 0.08 \\
\hline
\end{tabular}

were estimated using the Wood lactation curve (Wood, 1967). The most recent SCC measurement before the $\mathrm{CM}$ case depended on the causal pathogen and the parity of the cow. The most recent SCC measurement (categorized into $<200,000,200,000$ to 500,000 , and $>500,000$ cells $/ \mathrm{mL}$ ) was determined using a discrete probability distribution.

Probability distributions to determine the parity, month in milk, most recent SCC, and whether the cow with CM was systemically ill were based on data as used by Steeneveld et al. (2009). The probabilities to determine whether the CM case was a repeated case were based on Döpfer et al. (1999) and Swinkels et al. $(2005 \mathrm{a}, \mathrm{b})$. All of these probabilities are presented in Tables 1, 2, and 3 .

\section{Simulation of Follow-Up of Treatment Regimens for CM}

For each simulated CM case, the follow-up using different antimicrobial treatment regimens was simulated simultaneously. In total, 5 antimicrobial treatment regimens were defined, differing in route of application [3-d intramammary with antimicrobials (IMM3); 5-d intramammary with antimicrobials (IMM5); 3-d intramammary + systemic with antimicrobials (IMM3_S); 3-d intramammary + systemic with antimicrobials + 1-d NSAID (IMM3_S_NSAID); and 5-d intramammary + systemic with antimicrobials (IMM5_S)], costs, milk withdrawal period, and total treatment time (Table 4). The follow-up of the antimicrobial treatment regimens is presented in Figure 1.

Treatment of the initial CM case (CM1) could result in complete cure (bacteriological + clinical cure), no cure (no bacteriological cure + no clinical cure), or clinical cure but no bacteriological cure (Figure 1). To determine this cure status, it was first determined whether CM1 was cured bacteriologically after antimicrobial treatment.

To make the probability of bacteriological cure cowspecific, maximum probabilities of bacteriological cure were first determined for each causal pathogen treated with each of the defined antimicrobial treatment regimens. Probability of bacteriological cure was highest (maximum) for a heifer, not systemically ill, in the first 60 DIM, with a most recent $\mathrm{SCC}<200,000$ cells $/ \mathrm{mL}$, and no CM history (Table 4). Because such maximum probabilities of bacteriological cure were not available in the literature, values from the following sources were adapted: McDougall (1998), Sol et al. (2000), McDougall (2003), Oliver et al. (2003), Wraight (2003), Sérieys et al. (2005), McDougall et al. (2007), and Bradley and Green (2009). Literature information on the probability of bacteriological cure was limited for the intensive antimicrobial treatment regimens. Therefore, assumptions made by the authors were used to fill in all remaining maximum probabilities of bacteriological cure (Table 4). Subsequently, compared with the defined maximum probabilities of bacteriological cure, lower probabilities were assumed for older cows, for cows >60 DIM, for systemically ill cows, for cows with most recent SCC between 200,000 and 500,000 cells $/ \mathrm{mL}$, for cows with most recent $\mathrm{SCC}>500,000$ cells $/ \mathrm{mL}$, and for cows with a repeated $\mathrm{CM}$ case (Table 5). Information from the peer-reviewed literature and assumptions made by the authors were used to determine the effect of cow factors on the probability of bacteriological cure (Table 5). A cow-specific probability of bacteriological cure was cal-

Table 3. Probabilities used to determine the most recent SCC measurement, given the parity of the cow and the causal pathogen of clinical mastitis

\begin{tabular}{|c|c|c|c|c|c|c|}
\hline \multirow[b]{2}{*}{ Causal pathogen } & \multicolumn{3}{|c|}{$\begin{array}{c}\text { Parity } 1 \\
\mathrm{SCC}(\times 1,000 \text { cells } / \mathrm{mL})\end{array}$} & \multicolumn{3}{|c|}{$\begin{array}{c}\text { Parity } \geq 2 \\
\mathrm{SCC}(\times 1,000 \text { cells } / \mathrm{mL})\end{array}$} \\
\hline & $<200$ & $200-500$ & $>500$ & $<200$ & $200-500$ & $>500$ \\
\hline Streptococci & 0.34 & 0.22 & 0.44 & 0.41 & 0.17 & 0.42 \\
\hline Staphylococcus aureus & 0.40 & 0.25 & 0.35 & 0.35 & 0.20 & 0.45 \\
\hline Escherichia coli & 0.84 & 0.08 & 0.08 & 0.70 & 0.12 & 0.18 \\
\hline
\end{tabular}


Table 4. Characteristics of 5 defined clinical mastitis $(\mathrm{CM})$ antimicrobial treatment regimens

\begin{tabular}{|c|c|c|c|c|c|}
\hline \multirow[b]{2}{*}{ Characteristic } & \multicolumn{5}{|c|}{ Antimicrobial treatment regimen } \\
\hline & IMM3 & IMM5 & IMM3_S & IMM3_S_NSAID & IMM5_S \\
\hline Application and duration (d) & Intramammary (3) & Intramammary (5) & $\begin{array}{l}\text { Intramammary }(3) \\
\quad+\text { systemic }(3)\end{array}$ & $\begin{array}{c}\text { Intramammary }(3)+ \\
\text { systemic }(3)+ \\
\text { nonsteroidal } \\
\text { antiinflammatory drug }(1)\end{array}$ & $\begin{array}{c}\text { Intramammary }(5)+ \\
\text { systemic }(3)\end{array}$ \\
\hline Total cost of antibiotics $(\$)$ & 19 & 32 & 57 & 69 & 70 \\
\hline Milk withdrawal (d) & 5 & 7 & 5 & 5 & 7 \\
\hline Total treatment time ${ }^{1}(\min )$ & 42 & 62 & 45 & 48 & 65 \\
\hline \multicolumn{6}{|l|}{ Probability of bacteriological cure ${ }^{2}$} \\
\hline Streptococcus dysgalactiae or uberis & $0.70^{3}$ & $0.80^{4}$ & $0.80^{5}$ & $0.83^{5}$ & $0.90^{5}$ \\
\hline Staphylococcus aureus & $0.40^{6}$ & $0.60^{7}$ & $0.60^{5}$ & $0.63^{5}$ & $0.70^{5}$ \\
\hline Escherichia coli & $0.80^{8}$ & $0.80^{5}$ & $0.80^{5}$ & $0.80^{5}$ & $0.80^{5}$ \\
\hline $\begin{array}{l}\text { Probability of clinical cure for bacteriologically } \\
\text { noncured CM cases }\end{array}$ & $0.80^{5}$ & $0.80^{5}$ & $0.80^{5}$ & $0.80^{5}$ & $0.80^{5}$ \\
\hline
\end{tabular}

${ }^{1}$ Includes time for treatment and time for milk withdrawal.

${ }^{2}$ Probability of bacteriological cure assumed for heifers, not systemically ill, $<60$ DIM, with SCC $<200,000$ cells/mL, and no previous clinical mastitis.

${ }^{3}$ Adapted from McDougall (1998); McDougall (2003); Oliver et al. (2003); Wraight (2003); Sérieys et al. (2005); McDougall et al. (2007); Bradley and Green (2009).

${ }^{4}$ Adapted from Oliver et al. (2003).

${ }^{5}$ Estimated by the authors.

¿̆ $\quad{ }^{6}$ Adapted from Sol et al. (2000); McDougall (2003); Wraight (2003); Sérieys et al. (2005); McDougall et al. (2007); Bradley and Green (2009).

${ }^{7}$ Adapted from Sol et al. (2000)

$\stackrel{8}{8}$ Adapted from Sérieys et al. (2005); Bradley and Green (2009). 


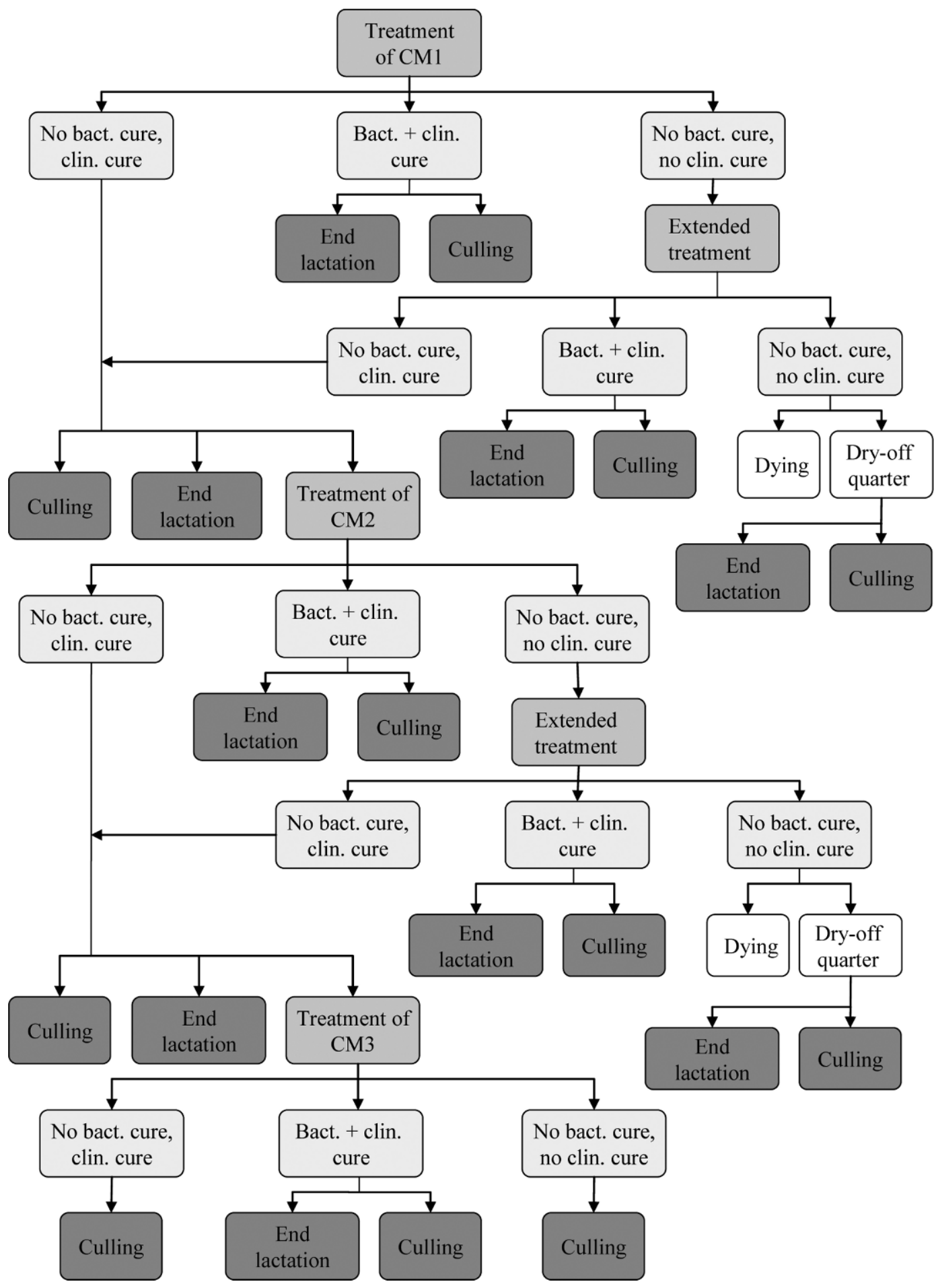

Figure 1. Schematic representation of the simulation model for antimicrobial treatment of a clinical mastitis $(\mathrm{CM})$ case $($ bact. $=$ bacteriological, clin. = clinical).

culated for each simulated cow with CM treated with each of the 5 defined antimicrobial treatment regimens using the defined maximum probability of bacteriological cure and the defined effects of the cow factors on the probability of bacteriological cure. The cow-specific probability of bacteriological cure $\left(P_{\text {Bact.cure }}\right)$ was calculated with the following equation, using a logit formula: 


$$
P_{\text {Bact.cure }}=\frac{1}{\left\{1+\operatorname{Exp}\left[-1 \times\left(\ln \left(\frac{C_{\text {max }}}{1-C_{\max }}\right)+\ln \left(\frac{C_{\text {parity }}}{C_{\text {max }}}\right)+\ln \left(\frac{C_{S y s}}{C_{\text {max }}}\right)+\ln \left(\frac{C_{D I M}}{C_{\text {max }}}\right)+\ln \left(\frac{C_{S C C}}{C_{\text {max }}}\right)+\ln \left(\frac{C_{R}}{C_{\text {max }}}\right)\right)\right]\right]},
$$

where $C_{\max }$ is the maximum probability of bacteriological cure for the combination of causal pathogen and treatment regimen (Table 4 ), and $C_{\text {parity }}, C_{\text {Sys }}, C_{D I M}$, $C_{S C C}$, and $C_{R}$ are the maximum probability of bacteriological cure (Table 4) minus the effect of the cow factors (parity, systemically ill, DIM, most recent SCC, and repeated $\mathrm{CM}$ ) on the probability of bacteriological cure (Table 5).

Subsequently, we determined whether the CM case was cured bacteriologically, or not, using a discrete probability distribution. Each bacteriologically cured CM case was assumed to be cured clinically as well. A discrete probability distribution was used to determine whether nonbacteriological cured CM cases were cured clinically or not. These probabilities of clinical cure are presented in Table 4.

Completely noncured CM cases received an extended treatment with the initial treatment regimen. Nonbacteriologically but clinically cured CM cases could have clinical flare-up cases (CM2 and CM3). These clinical flare-up cases were caused by the same pathogen as CM1 and were again treated with the initial treatment regimen. In addition, the follow-up of the extended treatment and the treatment of CM2 and CM3 were simulated (Figure 1). The follow-up was simulated using discrete probability distributions; the probabilities are presented in Table 5 .

A cow with a completely noncured $\mathrm{CM}$ case after an extended treatment could die or the quarter of the cow could be dried off. For cows with dried-off quarters, we determined whether this cow was culled in the remainder of the lactation (Table 5). A cow that cured completely had a probability of being culled, which depended on whether the CM case was the first, second, or third case (Table 5). A cow with a nonbacteriologically but clinically cured CM case had a probability of being culled, a probability of getting a clinical flare-up, and a probability of reaching the end of lactation. The probability of being culled increased with the number of $\mathrm{CM}$ cases (Table 5). The probabilities of being culled were 0.10 higher when the cow with CM was systemically ill.

A pert distribution was used to determine the day of occurrence of the potential first and second clinical flare-up cases. The minimum interval between clinical (flare-up) cases was $14 \mathrm{~d}$, the most likely interval between clinical flare-up cases was $30 \mathrm{~d}$, and the last day of occurrence of a clinical flare-up was the last day of lactation. For CM2 and CM3, the daily milk produc- tion at the day of occurrence (using the Wood lactation curve), the most recent SCC measurement, and whether the cow was systemically ill were determined again. It was assumed that a cow not cured bacteriologically after CM3 was culled $7 \mathrm{~d}$ after the day of treatment. For all other culled cows, the day of culling was in the remainder of lactation and was determined with a uniform probability distribution.

\section{Calculation of Costs}

The total costs for the defined CM treatment regimens included costs for treatment of CM1 (including antimicrobials, discarded milk and labor), costs for treatment of follow-up treatments (for extended treatments and treatments of clinical flare-up cases, including costs for antimicrobials, discarded milk and labor), costs for milk production losses and costs for culling. The original calculations were made in Euros and converted to US dollars using an exchange rate of 1.2725 (http:// www.x-rates.com/calculator.html; accessed Sep. 13, 2010). All costs presented herein are in US dollars.

Costs for antimicrobials for all defined treatment regimens are presented in Table 4 . Total costs of discarded milk were determined by daily milk production on the day of CM (estimated with Wood's lactation curve), milk withdrawal time (Table 4), and the economic value of discarded milk (Table 5). Total labor costs were determined by treatment time (for treating and milk withdrawal; Table 4) and the hourly cost of labor (Table 5).

Total costs for milk production loss were determined by the remaining milk production after the $\mathrm{CM}$ case (estimated with Wood's lactation curve), the percentage of milk production loss per month after CM, and the economic value of milk production loss (Table 5). The percentage of milk production loss per month after CM depended on the causal pathogen (Gröhn et al., 2004; Schukken et al., 2009), parity (Gröhn et al., 2004; Hagnestam et al., 2007; Schukken et al., 2009), month after CM (Schukken et al., 2009), whether the cow was systemically ill, and whether the cow was cured bacteriologically (Table 5). Milk production losses ranged from $6 \%$ (mo 1) to $1 \%$ (mo $\geq 8$ ) per month after $\mathrm{CM}$ for bacteriologically cured CM cases caused by streptococci in heifers that were not systemically ill. An additional milk production loss per month after CM was added for CM caused by Staph. aureus and E. coli, for CM in older 
Table 5. Values and source of parameters used in the simulation model for different antimicrobial treatment regimens for clinical mastitis $(\mathrm{CM})$

\begin{tabular}{|c|c|c|}
\hline Input parameters for simulation treatment of $\mathrm{CM}$ & Value & Source \\
\hline Parity $\geq 2$ & 0.10 & \multirow{5}{*}{ Expertise } \\
\hline $\mathrm{DIM} \geq \overline{6} 0$ & 0.10 & \\
\hline SCC $200,000-500,000$ cells $/ \mathrm{mL}$ & 0.10 & \\
\hline $\mathrm{SCC}>500,000$ cells $/ \mathrm{mL}$ & 0.20 & \\
\hline Repeated case & 0.20 & \\
\hline \multicolumn{2}{|l|}{ Probability of being culled for bacteriologically noncured CM cases } & \multirow[t]{2}{*}{ Adapted from Bar et al. (2008a) } \\
\hline First clinical flare-up case & 0.20 & \\
\hline \multicolumn{2}{|l|}{ Probability of being culled for completely cured CM cases } & \multirow[t]{4}{*}{ Adapted from Bar et al. (2008a) } \\
\hline Initial CM case & 0.05 & \\
\hline First clinical flare-up case & 0.15 & \\
\hline Second clinical flare-up case & 0.25 & \\
\hline Probability of mortality for nonclinical cured CM cases & 0.05 & \multirow{3}{*}{$\begin{array}{l}\text { Adapted from Bar et al. (2008a) } \\
\text { Expertise } \\
\text { Expertise } \\
\text { Expertise } \\
\text { Swinkels et al. (2005b); Swinkels et } \\
\text { al. (2005a); Döpfer et al. (1999) }\end{array}$} \\
\hline Probability of drying-off quarter for nonclinical cured CM cases & 0.95 & \\
\hline Escherichia coli & 0.05 & \\
\hline \multicolumn{3}{|l|}{ Increase in milk production losses per month in lactation ${ }^{2}(\%)$} \\
\hline Staphylococcus aureus & 2 & \multirow{5}{*}{$\begin{array}{l}\text { Adapted from Gröhn et al. } \\
(2004) \text {; Hagnestam et al. (2007); } \\
\text { Schukken et al. (2009) }\end{array}$} \\
\hline Escherichia coli & 4 & \\
\hline Parity $\geq 2$ & 5 & \\
\hline Systemically ill & 5 & \\
\hline Bacteriologically noncured & 5 & \\
\hline \multicolumn{3}{|l|}{ Economic input parameters } \\
\hline Economic value discarded milk $(\$ / \mathrm{kg})$ & 0.22 & \\
\hline Economic value milk production losses $(\$ / \mathrm{kg})$ & 0.15 & Huijps et al. (2008) \\
\hline Labor costs $(\$ / \mathrm{h})$ & 23 & Huijps et al. (2008) \\
\hline \multirow{2}{*}{ Culling costs $(\$)$} & Retention pay-off & Huijps et al. (2008) \\
\hline & & Houben et al. (1994); Van der Walle (2004) \\
\hline
\end{tabular}

${ }^{1}$ Compared with a heifer, not systemically ill, $<60$ DIM, with somatic cell count $<200,000$ cells/mL, and no previous clinical mastitis.

${ }^{2}$ Compared with a bacteriologically cured CM case caused by streptococci in heifers that were not systemically ill.

cows, for bacteriologically noncured CM cases, and for systemically ill cows (Table 5). Cows with a dried-off quarter had a total $15 \%$ milk production loss in the remainder of lactation. After a clinical flare-up case, milk production loss decreased by the same amount as after CM1 (Schukken et al., 2009). In the current study, a percentage milk production loss per month after CM was needed for a combination of cow factors. Because estimates on milk production losses were given in kilograms in most studies, we needed to adapt the values from the literature to percentages.

Culling costs were determined for culled cows and expressed using retention pay-off (RPO). The RPO values were calculated using a stochastic model developed by Houben et al. (1994). The model outcomes were updated by Van der Walle (2004) using values for prices and production level from the year 2003. With this model, culling costs were based on the specific cow factors parity, month of lactation, pregnancy status, and production level. For example, the culling costs for a pregnant cow in her second lactation with a very high production level were $\$ 975$, whereas those for a nonpregnant heifer with a very low production level were $\$ 146$.

\section{Validation and Sensitivity Analysis}

Because data were not available for external validation of the model, an internal validation was performed. A large number of inputs were compared with the output to check the consistency and the credibility of the model output.

A sensitivity analysis was performed to verify the values of the input parameters and to assess the effect of varying the input values on the outcome total costs of the treatment regimen. Values for input variables in the sensitivity analysis were based on information in the literature. Assumptions made by the authors were used if no information in the literature was found. The sensitivity analysis was performed on pathogen distri- 
Table 6. Average noneconomic output of the Monte Carlo simulation model

\begin{tabular}{|c|c|c|c|c|c|}
\hline Item & \multicolumn{5}{|c|}{ Antimicrobial treatment regimen $^{1}$} \\
\hline \multicolumn{6}{|l|}{ Probability of bacteriological cure for $\mathrm{CM}^{2}$} \\
\hline Staphylococcus aureus & 0.22 & 0.47 & 0.47 & 0.50 & 0.60 \\
\hline Escherichia coli & 0.74 & 0.74 & 0.74 & 0.74 & 0.74 \\
\hline Overall & 0.53 & 0.65 & 0.65 & 0.68 & 0.75 \\
\hline Staphylococcus aureus & 0.84 & 0.89 & 0.89 & 0.90 & 0.91 \\
\hline Escherichia coli & 0.94 & 0.94 & 0.94 & 0.94 & 0.94 \\
\hline Overall & 0.90 & 0.93 & 0.93 & 0.93 & 0.95 \\
\hline Overall probability of bacteriological cure for $\mathrm{CM} 2$ and $\mathrm{CM}^{3}{ }^{3}$ & 0.44 & 0.57 & 0.57 & 0.61 & 0.68 \\
\hline Culled cows $(\%)$ & 12 & 10 & 10 & 9 & 8 \\
\hline Milk production losses (\%) & 7 & 6 & 6 & 6 & 6 \\
\hline Extended treatments $(\%)$ & 10 & 7 & 7 & 5 & 3 \\
\hline
\end{tabular}

${ }^{1}$ IMM3 = standard 3-d intramammary treatment with antimicrobials; IMM5 = extended 5-d intramammary treatment with antimicrobials; IMM3_S = 3-d standard intramammary + systemic treatment with antimicrobials; IMM3_S_NSAID = standard 3-d intramammary + systemic treatment with antimicrobials + 1-d nonsteroidal antiinflammatory drug; and IMM5_S = extended 5-d intramammary + systemic treatment with antimicrobials.

${ }^{2}$ Treatment of the initial clinical mastitis $(\mathrm{CM})$ case.

${ }^{3}$ Treatment of the clinical flare-up cases.

bution, probability of culling, percentage milk production losses, probabilities of bacteriological cure, costs for culling, costs for labor, costs for milk production losses, and costs for milk withdrawal.

\section{RESULTS}

The outcome of treatment-specific parameters under default circumstances is presented in Table 6. On average, the overall probability of bacteriological cure for treatment of CM1 with IMM3, IMM5, IMM3_S, IMM3_S_NSAID, and IMM5_S was $0.53,0.65,0.65$, 0.68 , and 0.75 , respectively. On average, the overall probability of clinical cure for treatment of CM1 with IMM3, IMM5, IMM3_S, IMM3_S_NSAID, and IMM5_S was $0.90,0.93,0.93,0.93$, and 0.95 , respectively. Intensive antimicrobial treatment regimens resulted in fewer culled cows, fewer CM cases with an extended treatment, and fewer clinical flare-up cases. The total amount of milk production losses due to CM was approximately the same for all 5 antimicrobial treatment regimens.

On average, total costs for a CM case treated with IMM3 were $\$ 224$ (Table 7), and consisted of costs for the initial treatment $(\$ 66)$, follow-up treatments $(\$ 9)$, milk production losses $(\$ 95)$, and culling $(\$ 54)$. The total costs of CM treated with the intensive antimicrobial treatments were $\$ 247, \$ 253, \$ 260$, and $\$ 275$ for IMM5, IMM3_S, IMM3_S_NSAID, and IMM5_S, respectively. With increasing intensity of the antibiotic treatment regimen, the costs for milk production losses and culling decreased. These benefits of the intensive antimicrobial treatment regimens did not, however, outweigh the increasing costs for the initial treatment (costs for antibiotics, milk withdrawal, and labor). For instance, compared with IMM3, the average benefits of IMM5 were $\$ 9$ ( $\$ 4$ for less milk production loss and $\$ 5$ for less culling), whereas the average extra costs were $\$ 32$ (\$13 for antibiotics, $\$ 12$ for milk withdrawal, and $\$ 7$ for labor). In Table 7 , the variability in outcomes is shown using 5th and 95th percentiles. The range in outcomes was smaller for the intensive antimicrobial treatment regimens.

The causal pathogen and several cow characteristics influenced the total costs of CM treated with different treatment regimens (Table 8). On average, the total costs of a CM case caused by streptococci and treated with IMM3 was $\$ 196$, whereas the total costs of a Staph. aureus CM case treated with IMM3 was $\$ 255$. The costs of CM increased with increasing daily milk production at the moment of $\mathrm{CM}$, increasing relative production value, increasing parity number, and decreasing month in milk. In addition, for repeated CM cases and CM cases in systemically ill cows, the costs were higher than for nonrepeated cases and those in cows that were not systemically ill, respectively. Antimicrobial treatment of $\mathrm{CM}$ with IMM3 resulted in the lowest total costs for all causal pathogens and for all cow characteristics, with one exception: immediate culling resulted in the lowest total costs for cows with a low relative production value $(<80)$.

The association between total average costs and the probability of bacteriological cure is presented in Figure 2. Treatment of all simulated CM cases with IMM3 
Table 7. Average total costs $(\$)$ for the 6 clinical mastitis treatment regimens, including costs for the different cost factors $(5$ th and 95 th percentiles given between parentheses)

\begin{tabular}{|c|c|c|c|c|c|c|}
\hline \multirow[b]{2}{*}{ Cost $(\$)$} & \multicolumn{6}{|c|}{ Treatment regimen $^{1}$} \\
\hline & IMM3 & IMM5 & IMM3_S & IMM3_S_NSAID & IMM5_S & Culling \\
\hline \multicolumn{7}{|l|}{ Treatment $\mathrm{CM}^{2}{ }^{2}$} \\
\hline Antibiotics & 19 & 32 & 57 & 69 & 70 & 0 \\
\hline Milk withdrawal & $\begin{array}{l}31 \\
(11 ; 42)\end{array}$ & $\begin{array}{l}43 \\
(13 ; 60)\end{array}$ & $\begin{array}{l}31 \\
(11 ; 42)\end{array}$ & $\begin{array}{l}31 \\
(11 ; 42)\end{array}$ & $\begin{array}{c}43 \\
(13 ; 60)\end{array}$ & 0 \\
\hline Labor & 17 & 24 & 18 & 18 & 25 & 0 \\
\hline Milk production losses & $\begin{array}{l}95 \\
(25 ; 192)\end{array}$ & $\begin{array}{l}91 \\
(24 ; 185)\end{array}$ & $\begin{array}{l}90 \\
(23 ; 185)\end{array}$ & $\begin{array}{l}89 \\
(24 ; 181)\end{array}$ & $\begin{array}{l}87 \\
(24 ; 153)\end{array}$ & 0 \\
\hline Culling & $\begin{array}{l}53 \\
(0 ; 545)\end{array}$ & $\begin{array}{l}48 \\
(0 ; 484)\end{array}$ & $\begin{array}{l}47 \\
(0 ; 486)\end{array}$ & $\begin{array}{l}44 \\
(0 ; 445)\end{array}$ & $\begin{array}{l}42 \\
(0 ; 281)\end{array}$ & $\begin{array}{l}708 \\
(193 ; 1,224)\end{array}$ \\
\hline Total costs & $\begin{array}{l}224 \\
(79 ; 714)\end{array}$ & $\begin{array}{l}247 \\
(103 ; 720)\end{array}$ & $\begin{array}{l}253 \\
(116 ; 722)\end{array}$ & $\begin{array}{l}260 \\
(127 ; 714)\end{array}$ & $\begin{array}{l}275 \\
(140 ; 702)\end{array}$ & $\begin{array}{l}708 \\
(193 ; 1,224)\end{array}$ \\
\hline
\end{tabular}

${ }^{1}$ IMM3 = standard 3-d intramammary treatment with antimicrobials; IMM5 = extended 5-d intramammary treatment with antimicrobials; IMM3_S = 3-d standard intramammary + systemic treatment with antimicrobials; IMM3_S_NSAID = standard 3-d intramammary + systemic treatment with antimicrobials +1 -d nonsteroidal antiinflammatory drug; and IMM5_S = extended 5-d intramammary + systemic treatment with antimicrobials.

${ }^{2}$ Initial clinical mastitis (CM) case of the cow.

${ }^{3}$ Costs for antibiotics, milk withdrawal, and labor of the clinical flare-up cases.

resulted in the lowest total average costs but also in the lowest probability of bacteriological cure (0.53; Figure 2 ). The total costs and the probability of cure increased with the intensive antimicrobial treatments. Treatment regimens included on the least-cost frontier resemble those that were the most cost-effective. Because treatment with IMM3_S resulted in higher costs but the same probability of cure as treatment with IMM5, the IMM3_S treatment was not cost-effective and thus not included on the least-cost frontier. Total costs and probability of cure are also presented for an E. coli CM case, a Staph. aureus CM case, a CM case with a low probability of cure (older cow, $>60$ DIM, SCC >500,000 cells/mL, a previous CM case, and systemically ill), and for a CM case with a high probability of cure (heifer, $<60$ DIM, SCC $<200,000$ cell $/ \mathrm{mL}$, no previous CM, and not systemically ill) (Figure 2). Treatment with IMM3 resulted in the lowest total costs for these specific cows. The difference in total average costs between the antimicrobial treatment regimens was smaller for a cow with Staph. aureus CM than for a cow with a high probability of cure.

Results of the sensitivity analysis are given in Tables 9 and 10 . The pathogen distribution, the probability of culling a cow, the amount of milk production losses, the costs for culling, the costs for milk production losses, costs for discarded milk, and costs for labor influenced the total costs for CM treated with different treatment regimens. For instance, increasing the economic value of milk by $\$ 0.06$ increased the costs of CM treated with IMM3 by $\$ 50$. Treatment of CM with IMM3 resulted in the lowest total costs for all situations presented in Table 9.

Increasing probabilities of bacteriological cure resulted in lower costs for $\mathrm{CM}$ for all defined antimicrobial treatment regimens, whereas decreasing probabilities of bacteriological cure resulted in higher costs for CM (Table 10). By increasing the probability of bacteriological cure of streptococcal CM by 0.10 for all defined antimicrobial treatment regimens, the total costs of CM treated with IMM3 decreased by $\$ 9$ compared with the default situation. By increasing the probability of bacteriological cure of Staph. aureus and E. coli CM by 0.10 for all defined treatment regimens, the total costs of CM treated with IMM3 decreased by $\$ 10$ and $\$ 9$ compared with the default situation, respectively. By increasing the probability of bacteriological cure of the intensive antimicrobial treatment regimens (IMM5, IMM3_S, IMM3_S_NSAID, and IMM5_S) by 0.10 , treatment of CM with IMM5 resulted in the same total costs as treatment with IMM3.

\section{DISCUSSION}

In this study, total average costs for a CM case treated with IMM3 were $\$ 224$ (Table 7) and consisted of costs for the initial treatment (\$66), follow-up treatments (\$9), milk production losses (\$95), and culling (\$54). The total costs increased with the more intensive antibiotic treatment regimens. Compared with IMM3, treating with the intensive antibiotic treatment regimens resulted in benefits (Table 7) resulting from fewer 
Table 8. Average total costs $(\$)$ for the 6 treatment regimens for all cow characteristics

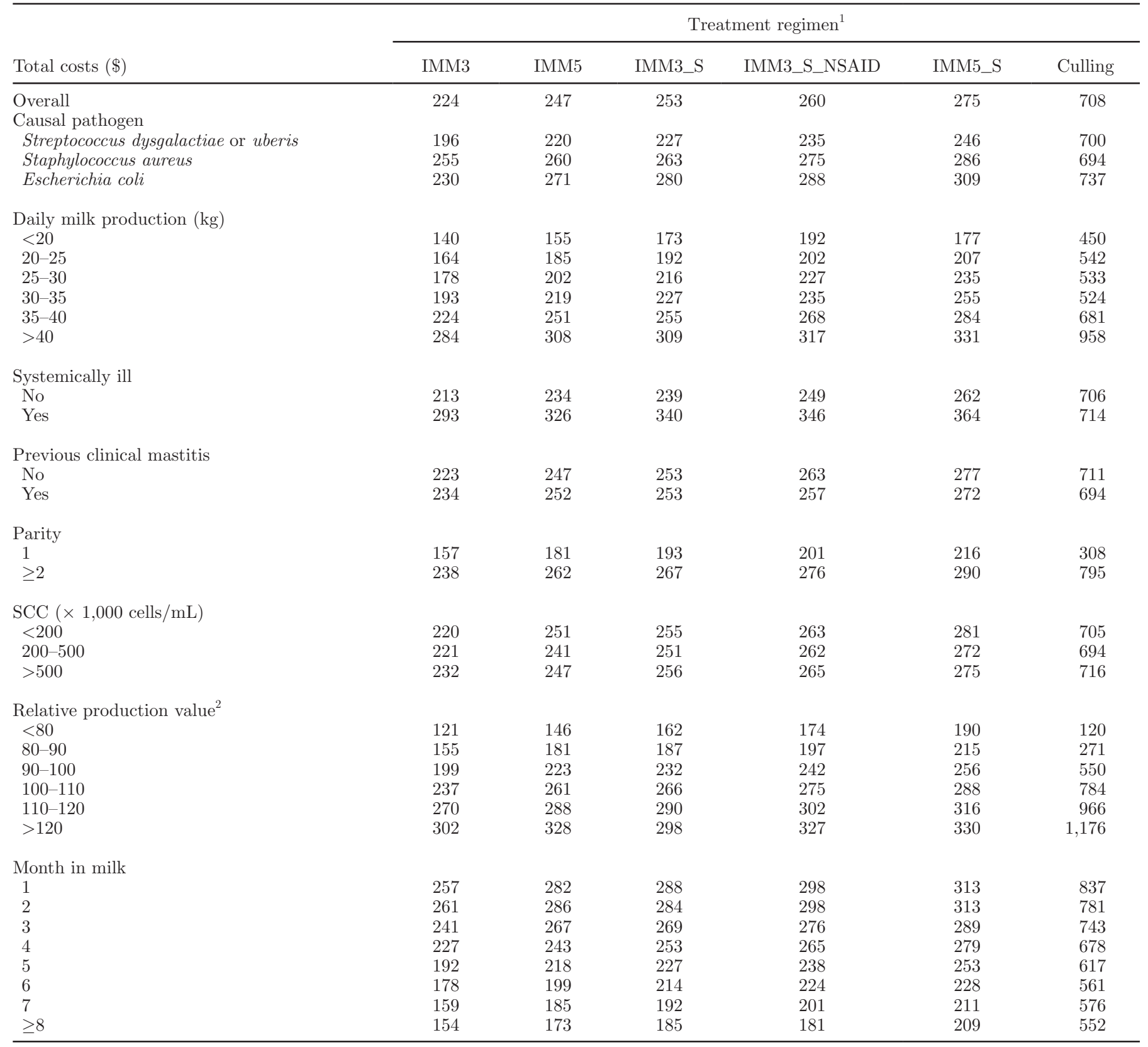

${ }^{1}$ IMM3 = standard 3-d intramammary treatment with antimicrobials; IMM5 = extended 5-d intramammary treatment with antimicrobials; IMM3_S = 3-d standard intramammary + systemic treatment with antimicrobials; IMM3_S_NSAID = standard 3-d intramammary + systemic treatment with antimicrobials + 1-d nonsteroidal antiinflammatory drug; and IMM5_S = extended 5-d intramammary + systemic treatment with antimicrobials.

${ }^{2}$ Represents index for 305-d milk production. A cow with a 305-d milk production of 8,500 kg has a relative production value of 100 .

follow-up treatments, less milk production loss, and less culling (Table 6). These benefits did not, however, outweigh the extra treatment costs (costs for antibiotics, milk withdrawal, and labor; Table 7). Additionally, for all different cow characteristics (Table 8 and Figure 2) and under different circumstances (Table 9), treatment of CM with IMM3 always resulted in the lowest total costs. For all different cow characteristics, the benefits of the intensive antibiotic treatment regimens on decreased costs for follow-up treatments, milk production losses, and culling did not outweigh the extra treatment costs for the initial CM case. Based on our assumptions, cow-specific treatment of CM was not economically beneficial. 


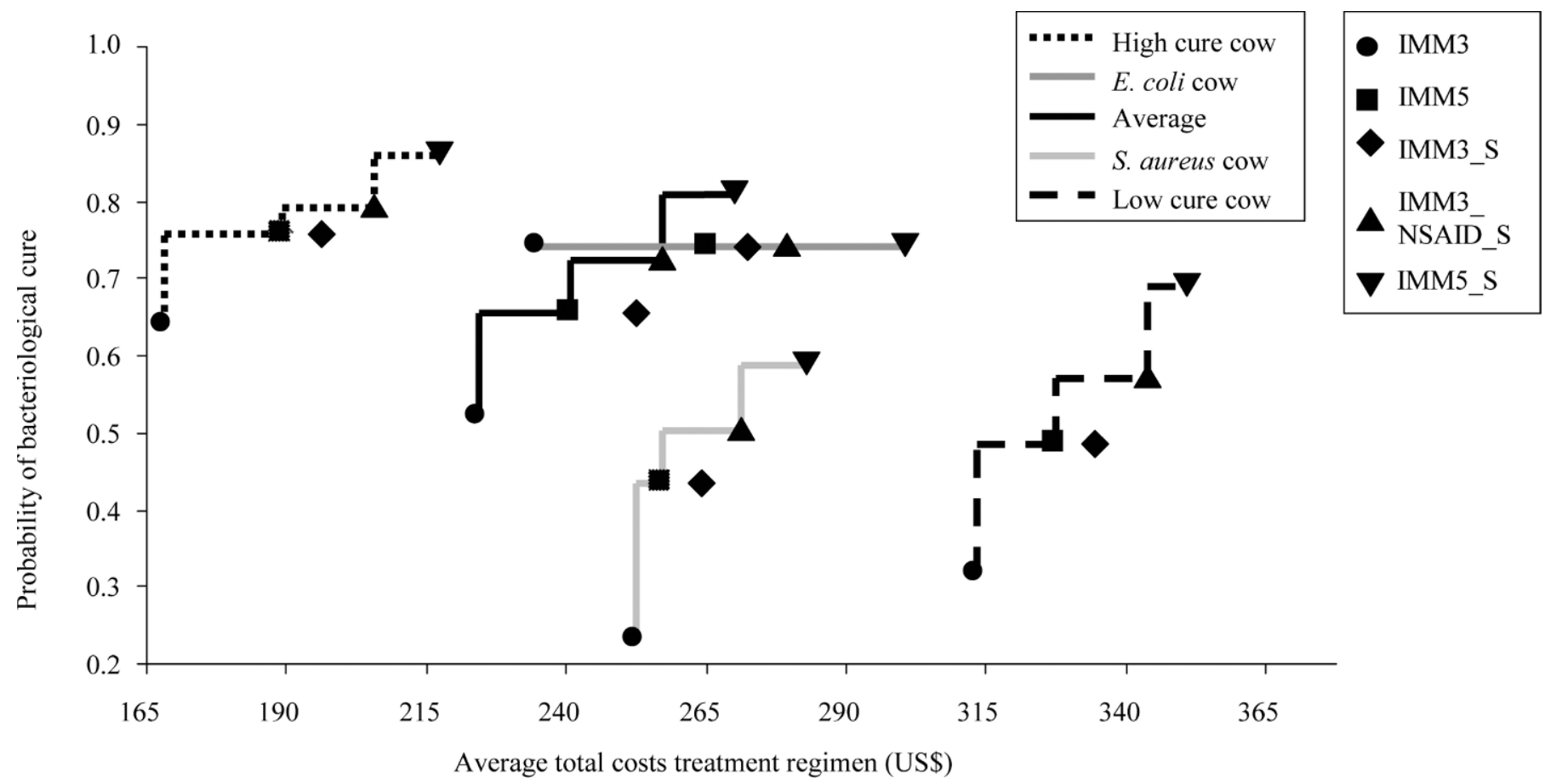

Figure 2. Average total costs for each antimicrobial treatment regimen with their associated average probability of bacteriological cure for different cows (IMM3 = standard 3-d intramammary treatment with antimicrobials; IMM5 = extended 5-d intramammary treatment with antimicrobials; IMM3_S = 3-d standard intramammary + systemic treatment with antimicrobials; IMM3_S_NSAID = standard 3-d intramammary + systemic treatment with antimicrobials + 1-d nonsteroidal antiinflammatory drug; and IMM5_S $=$ extended 5-d intramammary + systemic treatment with antimicrobials). The lines resemble the least-cost frontier of treatment for the different clinical mastitis cases. $E$. coli $=$ Escherichia coli; S. aureus = Staphylococcus aureus.

Results of the current study are highly influenced by the assumptions used; therefore, the results will not be applicable to all farm situations. Because of a lack of detailed information, as was needed for our model, several assumptions had to be made. These assumptions included the pathogen distribution used, the probabilities of cure and culling used, and an assumption that all defined treatments were effective against both grampositive and gram-negative pathogens. The pathogen distribution used, with the high probability of Staph. aureus, might not reflect reality for non-Dutch farms. All probabilities of cure used in the current simulation model were based as much as possible on information in the peer-reviewed literature. Although many clinical trials on treatment of CM have been performed (e.g., Sérieys et al., 2005; McDougall et al., 2007; Bradley and Green, 2009), detailed information on the probability of cure necessary for the current simulation model was not available in literature. Pathogen-specific probabilities of bacteriological and clinical cure were available for treatment with IMM3 (e.g., McDougall, 1998, 2003; Wraight, 2003), but pathogen-specific probabilities of cure were only reported in 3 studies for the more intensive antibiotic treatment regimens (Sol et al., 2000; Oliver et al., 2003; Taponen et al., 2003). Moreover, it was necessary to adapt available average probabilities of cure to maximum probabilities of cure because cowspecific probabilities were needed for the simulations. In addition, estimates on the effect of cow factors on the probability of cure were necessary. Although some studies indicated that cow factors influenced the probability of cure (Sol et al., 2000; Bradley and Green, 2009), usable estimates on the effects were not available. Assumptions made by the authors were used to determine all missing probabilities of cure, to adapt all average probabilities to maximum probabilities of cure, and to determine the effect of cow factors on the probability of cure. A lot of uncertainty existed about the used probabilities of cure, and thus the sensitivity analysis was important to verify our estimates.

The probabilities of bacteriological cure used influenced the total costs of CM. Higher probabilities of cure resulted in lower costs for CM. Increasing or decreasing the probabilities of bacteriological cure, however, did not result in lower total costs for the intensive antibiotic treatment regimens than for the standard antibiotic treatment regimen (Table 10). Increasing the probability of bacteriological cure for IMM5 by 0.10 resulted in equal total costs $(\$ 224)$ for treatment with IMM3 and IMM5 (Table 10). This implies that the benefits of treating with IMM5 almost outweighed the extra treatment costs. Therefore, the difference in probability 
Table 9. Sensitivity of the total costs $(\$)$ of clinical mastitis $(\mathrm{CM})$ treated with 6 treatment regimens for different input values

\begin{tabular}{|c|c|c|c|c|c|c|c|c|}
\hline \multirow[b]{2}{*}{ Item } & \multirow[b]{2}{*}{ Value } & \multirow[b]{2}{*}{ Default } & \multicolumn{6}{|c|}{ Treatment regimen $^{1}$} \\
\hline & & & IMM3 & IMM5 & IMM3_S & IMM3_S_NSAID & IMM5_S & Culling \\
\hline Default situation & & & 224 & 247 & 253 & 260 & 275 & 708 \\
\hline $\begin{array}{l}\text { Pathogen distribution (streptococci; } \\
\text { Staphylococcus aureus; Escherichia coli) }\end{array}$ & $\begin{array}{l}0.60 ; 0.20 ; 0.20 \\
0.20 ; 0.60 ; 0.20 \\
0.20 ; 0.20 ; 0.60\end{array}$ & $\begin{array}{l}0.40 ; 0.30 ; 0.30 \\
0.40 ; 0.30 ; 0.30 \\
0.40 ; 0.30 ; 0.30\end{array}$ & $\begin{array}{l}219 \\
234 \\
234\end{array}$ & $\begin{array}{l}239 \\
253 \\
252\end{array}$ & $\begin{array}{l}249 \\
258 \\
261\end{array}$ & $\begin{array}{l}255 \\
267 \\
275\end{array}$ & $\begin{array}{l}265 \\
285 \\
291\end{array}$ & $\begin{array}{l}708 \\
708 \\
708\end{array}$ \\
\hline $\begin{array}{l}\text { Probability of culling for bacteriologically } \\
\text { noncured CM cases }\end{array}$ & $\begin{array}{l}0.21 ; 0.25^{2} \\
0.11 ; 0.15^{2}\end{array}$ & $\begin{array}{l}0.16 ; 0.20^{2} \\
0.16 ; 0.20^{2}\end{array}$ & $\begin{array}{l}237 \\
218\end{array}$ & $\begin{array}{l}255 \\
243\end{array}$ & $\begin{array}{l}261 \\
249\end{array}$ & $\begin{array}{l}270 \\
261\end{array}$ & $\begin{array}{l}279 \\
279\end{array}$ & $\begin{array}{l}708 \\
708\end{array}$ \\
\hline Probability of culling for completely cured CM cases & 0 & $0.05 ; 0.15 ; 0.25^{3}$ & 211 & 227 & 232 & 242 & 255 & 708 \\
\hline Milk production losses per month in lactation (\%) & $\begin{array}{l}6-30^{4} \\
1-20^{4}\end{array}$ & $\begin{array}{l}1-25^{4} \\
1-25^{4}\end{array}$ & $\begin{array}{l}260 \\
187\end{array}$ & $\begin{array}{l}279 \\
209\end{array}$ & $\begin{array}{l}288 \\
216\end{array}$ & $\begin{array}{l}302 \\
229\end{array}$ & $\begin{array}{l}314 \\
243\end{array}$ & $\begin{array}{l}708 \\
708\end{array}$ \\
\hline Costs of culling $(\$)$ & $\begin{array}{l}\mathrm{RPO}^{5}+100 \\
\mathrm{RPO}-100\end{array}$ & $\begin{array}{l}\text { RPO } \\
\text { RPO }\end{array}$ & $\begin{array}{l}239 \\
210\end{array}$ & $\begin{array}{l}260 \\
228\end{array}$ & $\begin{array}{l}265 \\
238\end{array}$ & $\begin{array}{l}276 \\
244\end{array}$ & $\begin{array}{l}284 \\
265\end{array}$ & $\begin{array}{l}839 \\
579\end{array}$ \\
\hline Economic value of milk $(\$ / \mathrm{kg})$ & $\begin{array}{l}0.21^{6} ; 0.28^{7} \\
0.09^{6} ; 0.16^{7}\end{array}$ & $\begin{array}{l}0.15^{6} ; 0.22^{7} \\
0.15^{6} ; 0.22^{7}\end{array}$ & $\begin{array}{l}274 \\
176\end{array}$ & $\begin{array}{l}295 \\
191\end{array}$ & $\begin{array}{l}302 \\
202\end{array}$ & $\begin{array}{l}312 \\
218\end{array}$ & $\begin{array}{l}326 \\
228\end{array}$ & $\begin{array}{l}708 \\
708\end{array}$ \\
\hline Costs of labor $(\$ / \mathrm{h})$ & $\begin{array}{l}0 \\
12\end{array}$ & $\begin{array}{l}23 \\
23\end{array}$ & $\begin{array}{l}214 \\
215\end{array}$ & $\begin{array}{l}227 \\
232\end{array}$ & $\begin{array}{l}235 \\
232\end{array}$ & $\begin{array}{l}248 \\
255\end{array}$ & $\begin{array}{l}252 \\
265\end{array}$ & $\begin{array}{l}708 \\
708\end{array}$ \\
\hline
\end{tabular}

${ }^{1}$ IMM3 = standard 3-d intramammary treatment with antimicrobials; IMM5 = extended 5-d intramammary treatment with antimicrobials; IMM3_S = 3-d standard intramammary + systemic treatment with antimicrobials; IMM3_S_NSAID = standard 3-d intramammary + systemic treatment with antimicrobials + 1-d nonsteroidal antiinflammatory drug; and IMM5_S = extended 5-d intramammary + systemic treatment with antimicrobials.

${ }^{2}$ Dependent on culling due to the first clinical mastitis case or due to the first clinical flare-up case.

Dependent on culling due to the first clinical mastitis case, due to the first clinical flare-up case, or due to the second clinical flare-up case.

P ${ }^{4}$ Dependent on the causal pathogen, parity, month after $\mathrm{CM}$ case, whether cow is systemically ill, and whether CM is cured bacteriologically.

$\stackrel{\text { D. }}{\Xi}$ Retention pay-off.

( $\quad{ }^{6}$ Economic value for milk production losses.

$\stackrel{ก}{\bar{D}} \cdot{ }^{7}$ Economic value for discarded milk. 
Table 10. Sensitivity of the total costs $(\$)$ of clinical mastitis $(\mathrm{CM})$ treated with 5 different treatment regimens for input values on probability of bacteriological cure

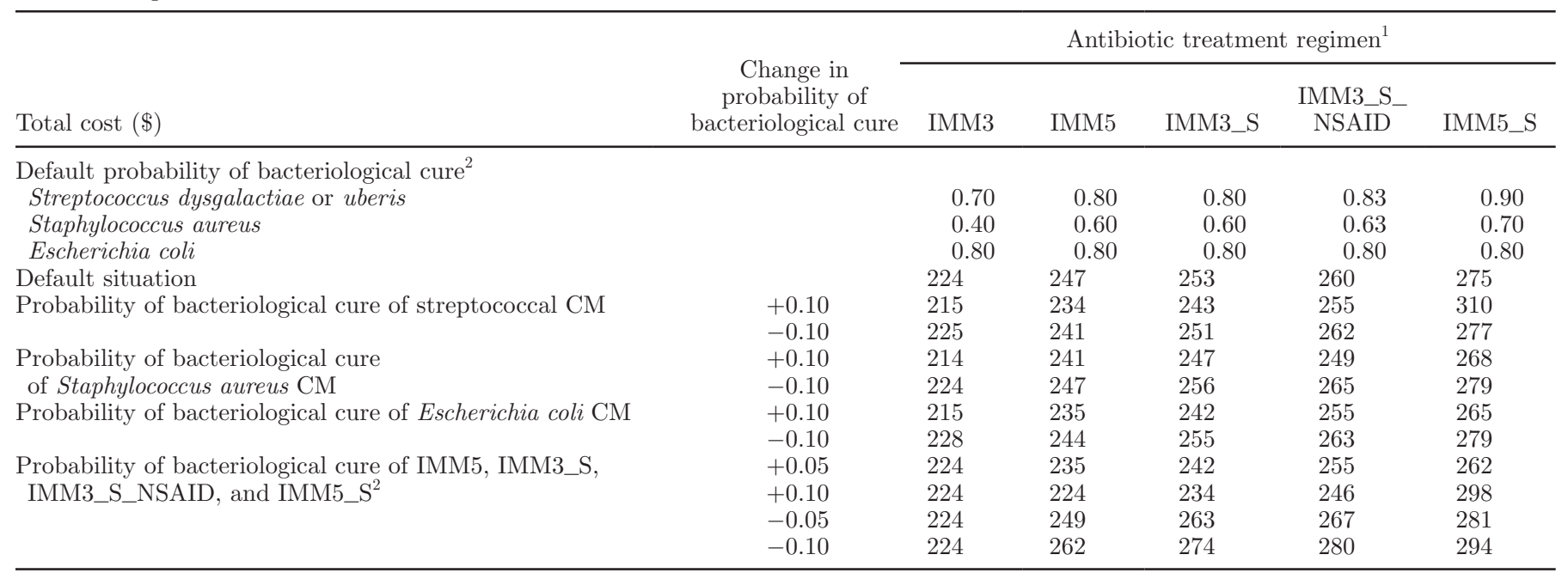

${ }^{1}$ IMM3 = standard 3-d intramammary treatment with antimicrobials; IMM5 = extended 5-d intramammary treatment with antimicrobials; IMM3_S = 3-d standard intramammary + systemic treatment with antimicrobials; IMM3_S_NSAID = standard 3-d intramammary + systemic treatment with antimicrobials + 1-d nonsteroidal antiinflammatory drug; and IMM5_S = extended 5-d intramammary + systemic treatment with antimicrobials.

${ }^{2}$ Probability of bacteriological cure assumed for heifers, not systemically ill, $<60$ DIM, with SCC $<200,000$ cells/mL, and no previous clinical mastitis.

of bacteriological cure between the defined treatment regimens influences whether cow-specific treatment is economically beneficial. Using our defined values on the probabilities of bacteriological and clinical cure, cowspecific treatment of CM is not economically beneficial. Nevertheless, this conclusion may change when results of future clinical trials on intensive antibiotic treatment regimens yield much higher probabilities of cure.

To determine if cow-specific treatment of $\mathrm{CM}$ is economically beneficial, treatment regimens that were used by Dutch dairy farmers were defined. In addition, Dutch economic values were used; for instance, on costs for culling, discarding milk, and labor. Other studies using Dutch input values also estimated the costs for CM cases treated with standard treatment regimens (Huijps et al., 2008; Halasa et al., 2009). The costs for a CM case of $\$ 224$ were lower than the $\$ 267$ found by Huijps et al. (2008). This was especially due to the probability of culling used in the current model, which was based on whether the CM case was the first case in the lactation or a follow-up case (Bar et al., 2008a), whether the cow was systemically ill, and the cure status. The costs for CM caused by streptococci, Staph. aureus, and E. coli of $\$ 196, \$ 253$, and $\$ 239$, respectively (Table 8) are in agreement with estimates found by Halasa et al. (2009). Milk production losses and culling contribute greatly to the total costs of CM (Table 7), as was also found by Huijps et al. (2008) and Halasa et al. (2009). In other countries, the costs for culling, discarding milk, and labor are different. Including dif- ferent economic input values influenced the total costs for CM, as was found in the results from the sensitivity analysis. Varying these economic input values did not, however, influence the result that treating $\mathrm{CM}$ with IMM3 resulted in the lowest total costs. To adapt the model to other countries, country-specific economic input values are needed.

Including culling in the current model was difficult. Culling is a decision of the dairy farmer and several factors are involved: not only udder health status, but also factors such as milk production, reproduction status (e.g., Lehenbauer and Oltjen, 1998), the milk quota situation of the farm, and the availability of replacement heifers play a role in the decision to cull a cow. Including all these factors is very difficult and was not included in our study.

The costs of culling make a substantial contribution to the total costs of CM and influence the amount of benefits of the intensive antibiotic treatment regimens (Table 7). The costs of culling were based on the RPO value of the cow, and this value represents the amount of money that should be spent in trying to keep the cow in case of health problems (e.g., Groenendaal et al., 2004). The RPO value of a cow varies between farms and estimations are difficult to make. The results of the sensitivity analysis demonstrate, however, that increasing or decreasing the costs of culling a cow did not result in lower costs for the intensive antibiotic treatment regimens than for the standard antibiotic treatment regimen. Average total costs for immediate culling of a 
cow with CM were $\$ 708$. This value was much higher than the average total costs for the 5 antimicrobial treatment regimens (Table 7); therefore, immediate culling of a cow with CM is unprofitable.

It would be interesting to include a no-treatment scenario in our model. We decided not to include this scenario for 2 reasons. First, in the Netherlands, almost all CM cases are treated with antimicrobials. Nontreatment of CM cases is very rare, and therefore including this scenario does not reflect reality for Dutch farms. Second, very detailed information was needed for our model; for instance, for the bacteriological cure. Few reports exist on leaving CM cases untreated (Guterbock et al., 1993; Roberson et al., 2004); therefore, for the authors (and other experts), it was very difficult to give cure estimates for the no-treatment scenario, and thus we decided not to include it. We expect that including the no-treatment scenario based on best guesses would not reflect reality and could result in erroneous conclusions.

Benefits of CM treatment also include prevention of mastitis in other cows on the farm. Halasa et al. (2009) mentioned the importance of transmission of pathogens for the costs of CM. van den Borne et al. (2010) showed that lactational treatment of contagious subclinical mastitis seems economically beneficial in dairy herds that implement management measures to decrease the transmission of contagious mastitis pathogens such as Staph. aureus. The intensive antibiotic treatment regimens resulted in higher probabilities of bacteriological cure than did the standard treatment regimen (Table 6 ), and these intensive treatment regimens will therefore prevent more new CM cases in other cows than would the standard treatment regimen. It is expected that also including these benefits will favor the intensive antibiotic treatment regimens more. To include these benefits, the within-herd dynamics of infection must be included and development of a herd-level model would be necessary. The model developed in our study simulated single CM cases, and it was not possible to properly include within-herd dynamics of infection.

Dairy farmers do not always make cost-effective decisions, and factors other than the costs influence mastitis management decisions (Valeeva et al., 2007). For specific cows with CM, farmers will prefer a treatment that results in the highest probability of cure instead of the lowest total cost. Making these decisions will not result in a cost-effective decision, but for some farmers a cured cow is more important. For some specific CM cases, the extra amount of money needed to reach a higher probability of cure is small. For instance, treating with IMM5 instead of IMM3 for a Staph. aureus $\mathrm{CM}$ will result in an additional $\$ 5$, but the probability of cure will increase by 0.25 (Figure 2). This implies that using the intensive antibiotic treatments for Staph. aureus $\mathrm{CM}$ is more economically beneficial than for CM cases caused by other pathogens. Bacteriological culture results are available too late; therefore, the choice of treatment needs to be made before knowing the causal pathogen. Several models, however, were developed that can aid in diagnosis of the causal pathogen (Jones and Ward, 1990; Heald et al., 2000; de Haas et al., 2004; Steeneveld et al., 2009).

Recently, promising results have been presented about on-farm culture systems to determine the causal pathogen of CM (Lago et al., 2009; Keefe et al., 2010). For mild or moderate CM cases, no difference in probability of cure (Keefe et al., 2010), CM recurrence, SCC, milk production, or culling (Lago et al., 2009) was observed between CM cases treated immediately and cases treated $24 \mathrm{~h}$ after detection. It would be very interesting to evaluate the use of these on-farm diagnostic tests economically. Stochastic simulation would be a suitable tool to do so. Compared with the current model, the model structure would be different: all possible outcomes of on-farm bacteriological culture would have to be included, including major and minor pathogens and bacteriological negative outcomes.

With increasing automation on dairy farms, the possibilities for automated individual cow management have increased. Automated decision support on choice of CM treatment for individual cows is an example of automated individual cow management. To determine whether it is worthwhile to include choice of treatment in decision support models, we need to determine if choosing different antibiotic treatment for different cows is economically beneficial. Because of the cow-specific probabilities of cure, we expected that cow-specific treatment would be economically beneficial. Based on our assumptions, however, cow-specific treatment of CM was not economically beneficial.

\section{ACKNOWLEDGMENTS}

This research was supported by the Dutch Technology Foundation STW (The Hague, the Netherlands), applied science division of NWO (The Hague, the Netherlands), and the Technology Program of the Dutch Ministry of Economic Affairs (The Hague, the Netherlands).

\section{REFERENCES}

Bar, D., Y. T. Gröhn, G. Bennett, R. N. Gonzalez, J. A. Hertl, H. F. Schulte, L. W. Tauer, F. L. Welcome, and Y. H. Schukken. 2008a. Effects of repeated episodes of generic clinical mastitis on mortality and culling in dairy cows. J. Dairy Sci. 91:2196-2204.

Bar, D., L. W. Tauer, G. Bennett, R. N. Gonzalez, J. A. Hertl, Y. H. Schukken, H. F. Schulte, F. L. Welcome, and Y. T. Gröhn. 2008b. 
The cost of generic clinical mastitis in dairy cows as estimated by using dynamic programming. J. Dairy Sci. 91:2205-2214.

Barkema, H. W., Y. H. Schukken, T. J. G. M. Lam, M. L. Beiboer, H. Wilmink, G. Benedictus, and A. Brand. 1998. Incidence of clinical mastitis in dairy herds grouped in three categories by bulk milk somatic cell counts. J. Dairy Sci. 81:411-419.

Barkema, H. W., Y. H. Schukken, and R. N. Zadoks. 2006. Invited review: The role of cow, pathogen, and treatment regimen in the therapeutic success of bovine Staphylococcus aureus mastitis. J. Dairy Sci. 89:1877-1895.

Bradley, A. J., and M. J. Green. 2009. Factors affecting cure when treating bovine clinical mastitis with cephalosporin-based intramammary preparations. J. Dairy Sci. 92:1941-1953.

CRV. 2009. www.cr-delta.nl Accessed July 16, 2010.

de Haas, Y., R. F. Veerkamp, H. W. Barkema, Y. T. Gröhn, and Y. H. Schukken. 2004. Associations between pathogen-specific cases of clinical mastitis and somatic cell count patterns. J. Dairy Sci. $87: 95-105$.

Döpfer, D., H. W. Barkema, T. J. G. M. Lam, Y. H. Schukken, and W. Gaastra. 1999. Recurrent clinical mastitis caused by Escherichia coli in dairy cows. J. Dairy Sci. 82:80-85.

Groenendaal, H., D. T. Galligan, and H. A. Mulder. 2004. An economic spreadsheet model to determine optimal breeding and replacement decisions for dairy cattle. J. Dairy Sci. 87:2146-2157.

Gröhn, Y. T., D. J. Wilson, R. N. Gonzalez, J. A. Hertl, H. Schulte, G. Bennett, and Y. H. Schukken. 2004. Effect of pathogen-specific clinical mastitis on milk yield in dairy cows. J. Dairy Sci. 87:3358-3374.

Guterbock, W. M., A. L. Vaneenennaam, R. J. Anderson, I. A. Gardner, J. S. Cullor, and C. A. Holmberg. 1993. Efficacy of intramammary antibiotic-therapy for treatment clinical mastitis caused by environmental pathogens. J. Dairy Sci. 76:3437-3444.

Hagnestam, C., U. Emanuelson, and B. Berglund. 2007. Yield losses associated with clinical mastitis occurring in different weeks of lactation. J. Dairy Sci. 90:2260-2270.

Halasa, T., K. Huijps, O. Østeras, and H. Hogeveen. 2007. Economic effects of bovine mastitis and mastitis management: A review. Vet. Q. 29:18-31.

Halasa, T., M. Nielen, R. B. M. Huirne, and H. Hogeveen. 2009. Stochastic bio-economic model of bovine intramammary infection. Livest. Sci. 124:295-305.

Heald, C. W., T. Kim, W. M. Sischo, J. B. Cooper, and D. R. Wolfgang. 2000. A computerized mastitis decision aid using farm-based records: An artificial neural network approach. J. Dairy Sci. 83:711-720.

Houben, E. H. P., R. B. M. Huirne, A. A. Dijkhuizen, and A. R. Kristensen. 1994. Optimal replacement of mastitic cows determined by a hierarchical Markov process. J. Dairy Sci. 77:2975-2993.

Huijps, K., T. J. G. M. Lam, and H. Hogeveen. 2008. Costs of mastitis: Facts and perception. J. Dairy Res. 75:113-120.

Jones, G. F., and G. E. Ward. 1990. Evaluation of a scheme for predicting the gram staining reaction of organisms causing bovine mastitis. J. Am. Vet. Med. Assoc. 196:597-599.

Keefe, G., J. McCarron, K. MacDonald, and M. Cameron. 2010. The scientific bases for using on-farm culture systems. Pages 141-148 in Proc. 49th Ann. Mtg. NMC. National Mastitis Council, Madison, WI.

Lago, A., S. Godden, R. Bey, P. Ruegg, and K. Leslie. 2009. Effect of the selective treatment of clinical mastitis based in on-farm culture results on clinical mastitis recurrence, somatic cell count, milk production and culling. Pages 150-151 in Proc. 48th Ann. Mtg. NMC. National Mastitis Council, Madison, WI.

Lehenbauer, T. W., and J. W. Oltjen. 1998. Dairy cow culling strategies: Making economical culling decisions. J. Dairy Sci. 81:264271.

McDougall, S. 1998. Efficacy of two antibiotic treatments in curing clinical and subclinical mastitis in lactating dairy cows. N. Z. Vet. J. $46: 226-232$.

McDougall, S. 2003. Intramammary treatment of clinical mastitis of dairy cows with a combination of lincomycin and neomycin, or penicillin and dihydrostreptomycin. N. Z. Vet. J. 51:111-116.
McDougall, S., D. G. Arthur, M. A. Bryan, J. J. Vermunt, and A. M. Weir. 2007. Clinical and bacteriological response to treatment of clinical mastitis with one of three intramammary antibiotics. N. Z. Vet. J. 55:161-170.

McDougall, S., M. A. Bryan, and R. M. Tiddy. 2009. Effect of treatment with the nonsteroidal antiinflammatory meloxicam on milk production, somatic cell count, probability of re-treatment, and culling of dairy cows with mild clinical mastitis. J. Dairy Sci. 92:4421-4431.

Miller, G. A. 1956. The magical number 7, plus or minus 2-Some limits on our capacity for processing information. Psychol. Rev. 63:81-97.

Olde Riekerink, R. G. M., H. W. Barkema, and H. Stryhn. 2007. The effect of season on somatic cell count and the incidence of clinical mastitis. J. Dairy Sci. 90:1704-1715.

Oliver, S. P., R. A. Almeida, B. E. Gillespie, S. J. Ivey, H. Moorehead, P. Lunn, H. H. Dowlen, D. L. Johnson, and K. C. Lamar. 2003 Efficacy of extended pirlimycin therapy for treatment of experimentally induced Streptococcus uberis intramammary infections in lactating dairy cattle. Vet. Ther. 4:299-308.

Roberson, J. R., L. D. Warnick, and G. Moore. 2004. Mild to moderate clinical mastitis: Efficacy of intramammary amoxicillin, frequent milk-out, a combined intramammary amoxicillin, and frequent milk-out treatment versus no treatment. J. Dairy Sci. 87:583592.

Schukken, Y. H., J. Hertl, D. Bar, G. J. Bennett, R. N. Gonzalez, B. J. Rauch, C. Santisteban, H. F. Schulte, L. Tauer, F. L. Welcome, and Y. T. Gröhn. 2009. Effects of repeated gram-positive and gram-negative clinical mastitis episodes on milk yield loss in Holstein dairy cows. J. Dairy Sci. 92:3091-3105.

Sérieys, F., Y. Raguet, L. Goby, H. Schmidt, and G. Friton. 2005. Comparative efficacy of local and systemic antibiotic treatment in lactating cows with clinical mastitis. J. Dairy Sci. 88:93-99.

Sol, J., O. C. Sampimon, H. W. Barkema, and Y. H. Schukken. 2000. Factors associated with cure after therapy of clinical mastitis caused by Staphylococcus aureus. J. Dairy Sci. 83:278-284.

Steeneveld, W., L. C. van der Gaag, H. W. Barkema, and H. Hogeveen. 2009. Providing probability distributions for the causal pathogen of clinical mastitis using naive Bayesian networks. J. Dairy Sci. 92:2598-2609.

Swinkels, J. M., H. Hogeveen, and R. N. Zadoks. 2005a. A partial budget model to estimate economic benefits of lactational treatment of subclinical Staphylococcus aureus mastitis. J. Dairy Sci. $88: 4273-4287$

Swinkels, J. M., J. G. Rooijendijk, R. N. Zadoks, and H. Hogeveen. 2005b. Use of partial budgeting to determine the economic benefits of antibiotic treatment of chronic subclinical mastitis caused by Streptococcus uberis or Streptococcus dysgalactiae. J. Dairy Res. $72: 75-85$.

Taponen, S., K. Dredge, B. Henriksson, A. M. Pyyhtia, L. Suojala, R. Junni, K. Heinonen, and S. Pyörälä. 2003. Efficacy of intramammary treatment with procaine penicillin $\mathrm{G}$ vs. procaine penicillin $\mathrm{G}$ plus neomycin in bovine clinical mastitis caused by penicillinsusceptible, gram-positive bacteria-A double blind field study. J. Vet. Pharmacol. Ther. 26:193-198.

Valeeva, N. I., T. J. G. M. Lam, and H. Hogeveen. 2007. Motivation of dairy farmers to improve mastitis management. J. Dairy Sci. 90:4466-4477.

van den Borne, B. H. P., T. Halasa, G. van Schaik, H. Hogeveen, and M. Nielen. 2010. Bioeconomic modeling of lactational antimicrobial treatment of new bovine subclinical intramammary infections caused by contagious pathogens. J. Dairy Sci. 93:4034-4044.

Van der Walle, K. 2004. Gebruikswaarde van melkvee. Internal report. Animal Sciences Group Wageningen UR, Lelystad, the Netherlands.

Wood, P. D. P. 1967. Algebraic model of the lactation curve in cattle. Nature 216:164-165.

Wraight, M. D. 2003. A comparative efficacy trial between cefuroxime and cloxacillin as intramammary treatments for clinical mastitis in lactating cows on commercial dairy farms. N. Z. Vet. J. $51: 26-32$. 